LWSA

PAPER - OPEN ACCESS

\title{
The Impact of Mandatory Use Of Rupiah Currency to Indonesia Trade Value Competitiveness and Economic Growth
}

\author{
Author : Tumpak Silalahi \\ DOI $\quad: 10.32734 /$ lwsa.v1i2.205 \\ Electronic ISSN : :2654-7066 \\ Print ISSN : 2654-7058
}

Volume 1 Issue 2 - 2018 TALENTA Conference Series: Local Wisdom, Social and Arts

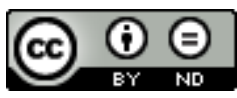

This work is licensed under a Creative Commons Attribution-NoDerivatives 4.0 International License.

Published under licence by TALENTA Publisher, Universitas Sumatera Utara
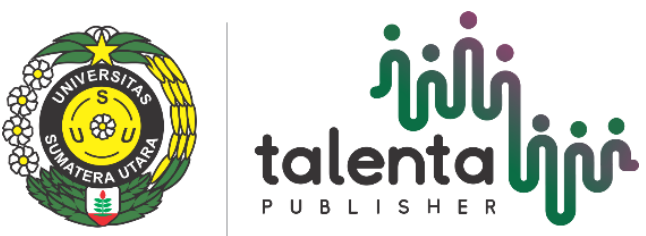


\title{
The Impact of Mandatory Use Of Rupiah Currency to Indonesia Trade Value Competitiveness and Economic Growth
}

\author{
Dr. Tumpak Silalahi
}

silalahi@bi.go.id

\begin{abstract}
Volatility of Rupiah's exchange rate to Foreign Currency in 2015 was indicated by Rupiah's depreciation. The purpose of this paper is to see how the implementation of mandatory use of Rupiah in Indonesia affects factors that cause its depreciation. In this paper, descriptive analysis and econometric analysis will be used to demonstrate and explain the impact of some variables to the amount of money circulated in the market. Bank Indonesia's RegulationNumber: 17/3/PBI/2015 was issued on March 31, 2015 and Circular Letter Number: 17/11/DKSP was issued on Juni 1, 2015 that it requiremandatory on the use of Rupiah in Indonesia territory. The policyconsists of economic, nationalism, and law perspectives. However, this paper focus only on the economic side with the main objective to see how it contributes to Rupiah's stability.By analysing quantitatively and qualitively data by using statistic procedure and simulation, this paper able to show the effect of policy measure on the financial condition as an aggregate figure during the period of research time.
\end{abstract}

Keywords: Mandatory Use of Rupiah; Payment System, Money in Circulation; Economic Transaction; Foreign Currecy Transactions. JEL code: E51, E52, E58

\section{Introduction}

In 2015, Bank Indonesia (BI) with some related government institutions created a policy that requires all transactions made in Indonesia to use Rupiah. This includes Bank Indonesia's regulation No. 17/3/PBI/2015 on March 31, 2015 and Letter No. 17/11/DKSP on June 1, 2015. These two correlate with Bill No. 7 in 2011 about currency. Transactions included in these laws are transactions that are used for payment, any obligations that have to be done using money, and/or any financial transaction, either cash or non-cash.

According to Bill No. 6 in 2009, BI as the holder of monetary and payment system otority in Indonesia has the right to rule the use of Rupiah in every transaction in Indonesia. BI's objective is to ensure Rupiah's stability as Indonesia's currency. The stability is measured in two components, which are Rupiah's stability towards goods and services and Rupiah's stability towards other currencies. The first component can be seen from inflation while the second component is seen from Rupiah's exachange rate.

Regulations that mandate the use of Rupiah in Indonesia will ensure Rupiah's competitiveness, purchasing power, and exchange rate. This regulation was based on trends of increasing number of the use of foreign currenciesin Indonesia as shown in Figure 1. 


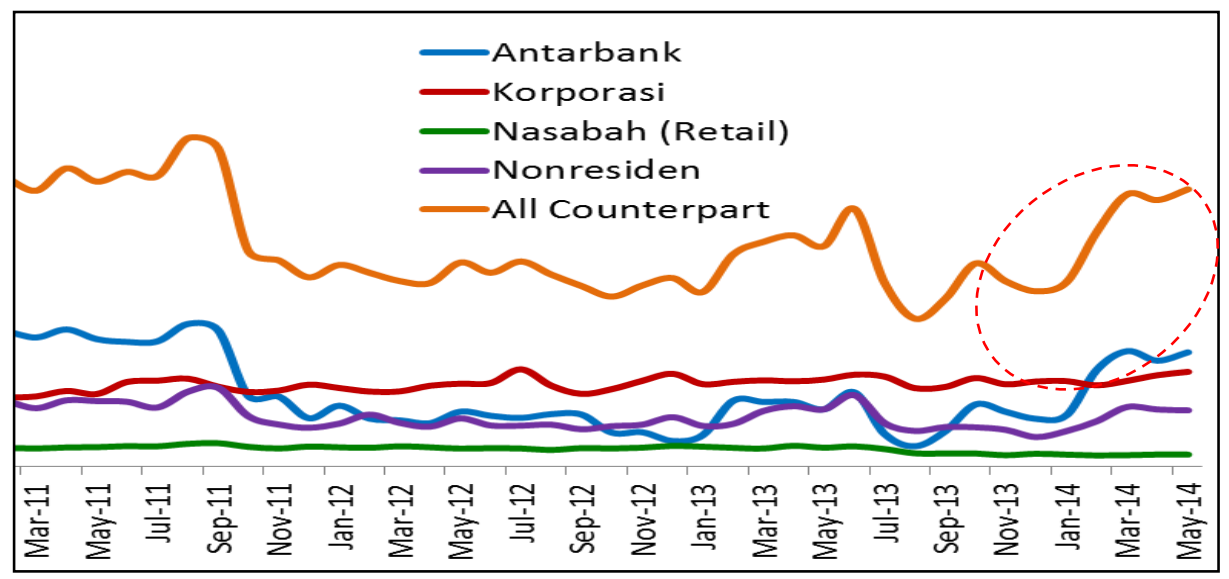

Figure.1. The Use of Foreign Currencies in Indonesia in May 2011 - May 2014.

Source: Bank Indonesia

According to Bank Indonesia's data, $94.6 \%$ of foreign currency transactions are in USD. It creates a high demand for USD that causes an imbalance of supply and demand of USD and Rupiah. As a result, Rupiah's exchange rate receives high pressure as illustrated in Figure 2.

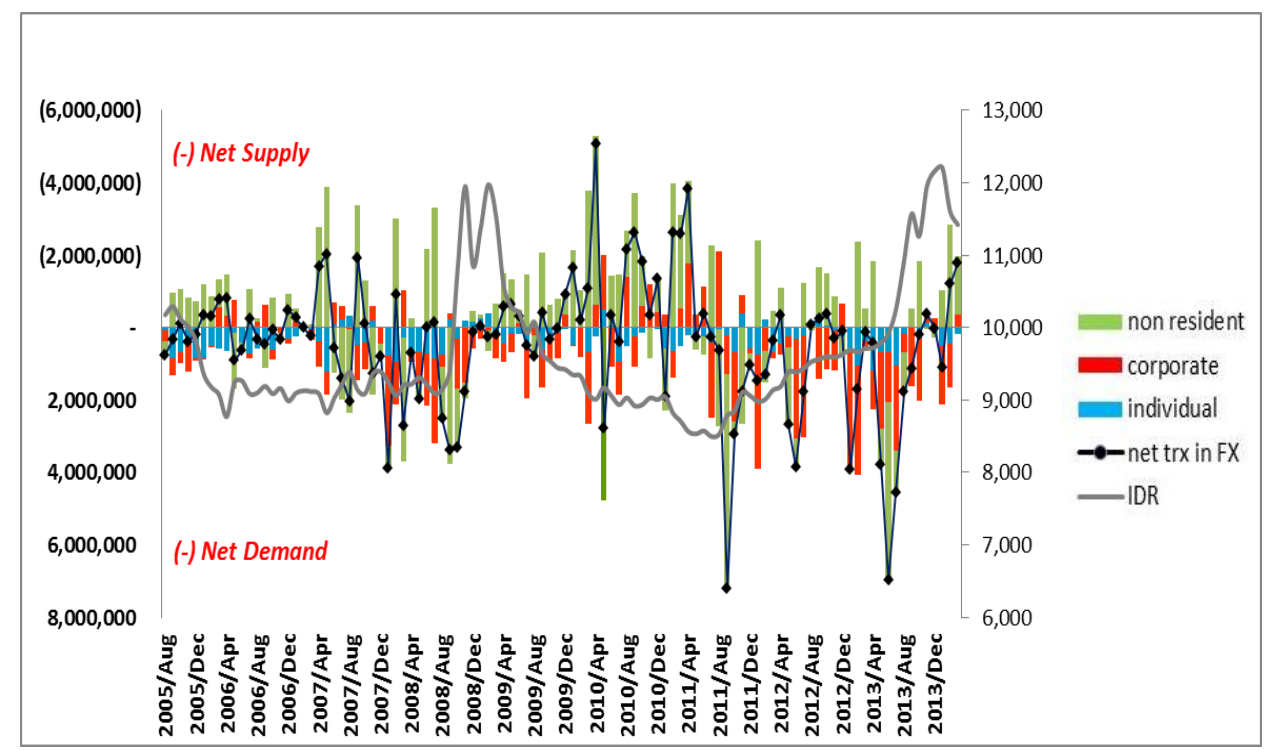

Figure. 2. Growth of Domestic Transaction in USD/IDR.

Source: Bank Indonesia

It makes Indonesia's economy vulnerable to economic wave. The net demand of USD for domestic transactions inputs pressure to the depreciation of Rupiah's exchange rate. It can intrude Rupiah's stability and bring complexity to monetary and exchange rate policy. Bank Indonesia realizes the importance of using Rupiah for domestic transaction in Indonesia as the foundation of a strong national economy. In the long run, it can prevent dollarization, so it can support a healthier economy.

Also, Bank Indonesia considers Rupiah's position that has not been recognized as a payment system worldwide. Because of that, there are some exceptions to the laws that will ensure that it does not limit economic activities that can bring negative effects to Indonesia's economy. These exceptions are: 
- Transaction in accordance with the nation's income and spendingbudget that includes Indonesia's debt payments (debt expense and its interest), foreign goods and capital purchase, and income from government's bonds

- Receiving from or giving grants tooffshore sources

- International trade transactions, which is export and/or import goods to or from foreign countries, and trade services done by cross border supply and/or consumption abroad

- Foreign currency savings in a bank that has foreign activities. Transactions that can be done are withdrawal and/or deposit in foreign currency

- International transaction if the sender or the receiver lives in foreign countries

The law to use Rupiah was implemented in March 2015 for cash transactions and in June 2015for non-cash transactions. As the regulator, it is important for Bank Indonesia to know the effectiveness of this law. Some agreement and disagreement was shown from different parties. Even though some private and public institutions support this regulation, data and analytic support is critical in determining its effectiveness. Therefore, this paper will answer the question of what is the effect of mandatory use of Rupiah in Indonesia to the amount of Rupiah circulated in the market. The amount of money circulated is one of the indicators of Rupiah's stability. By measuring this, we can see whether the regulation has a positive or a negative impact.

\section{Literature Review}

\subsection{Money Function}

Money in general is something that can be accepted generally as a payment system in a region or as a debt payment or to buy goods and services. In other words, money is a tool that is used in trading goods and services (Kasmir, 2011). On the other hand, currency determines the unit of money that is generally acceptable to be used as a payment system for goods and services and debt (Mishkin, 2008). Money plays an important role in a country's economy. It is the payment system and the measurement for price. It replaces old payment systems that are more complex, inefficient, and cannot be applied to modern economy since it requires another party who has the same desire and results in confusion in determining the value. Money's efficiency will encourage trade and better distribution of human capital which results in higher productivity.

In Indonesia, money was printed by the government (Djiwandono et al., 2006). However, after Bill No. 13 in 1968 Article 26 Chapter 1, the government's right to print money was lifted. Then, BI (as the central bank) got oktroil rights to be the only institution who has the right to print money.

There are two functions of money:

- $\quad$ Primary function

Money is used as medium of exchange, unit of account, and store of value. As a unit of account, money shows the value of goods and services, wealth, and debts. It is also used to quote price of goods and services. As a store of value, it enables people to save their money and use it for later purchase.

- Secondary function
a. For payment
b. Quoting price of goods and services
c. Debt payments
d. Wealth: Savings in checking or savings account have high liquidity, which is beneficial in urgent situation
e. Transferrable wealth. It can be transferred from one party to another or from one bank to another
f. Economy activities. A stabil value of a currency or money will encourage people to invest, which is good for the economy 
In Indonesia, money is classified into two categories, which are money printed by central bank and money printed by banks. The differences between these two are explained in Table 1 .

Table.1. Types and Characteristics of Money.

\begin{tabular}{lll}
\hline Description & Money printed by central banks & Money printed by banks \\
\hline Usage & Can be used by everyone & Can be used by certain individuals \\
Nominal & Printed and limited & According to the holder's need and unlimited \\
Guarantee & Guaranteed by the government & Guaranteed by banks who sell it and by the \\
& & government in a limited period \\
Example & Paper money and coins & Checks and deposits \\
\hline
\end{tabular}

\subsection{Demand and Supply of Money}

Keynes (1936) differentiates motifs of demand of money into three:

- Demand for transactions

Keynes argue that the demand for transactions depends on income. If income is high, transactions will be high too. People will higher income will have more transactions/consumption

- Demand for savings

It is used for unexpected expense, such as illness. It also depends on income. If income is high, demang for savings will be high too.

- $\quad$ Demand for investments

It depends on interest rate. If interest rate is high, people will be more reluctant to invest because the opportunity cost of withdrawing money is high, and there is an assumption that interest rate will go back to its normal level, and vice versa. Other factors that should be taken into consideration are time value of money and opportunity cost of having cash.

Factors that affected supply of money: interest rate, income, population, geographical condition, economic structure, human capital, globalisation, inflation, wealth, exchange rate, and credit facility provided by financial services.

\subsection{Money in Circulation}

Legal tender is the most important element in money in circulation in each country, especially in developing countries. In Indonesia, narrow money (M1) consists of money printed by central bank and banks. Broad money (M2) consists of M1, quasi money, and marketable securities besides stocks. Calculation of money in circulation can be done with two methods, which are accounting and behavior methods. Bank Indonesia uses accounting method with formula stated below.

$$
\begin{array}{ll}
\mathrm{M} 1 & =\mathrm{NFA}+\mathrm{DC}-\mathrm{TD}-\mathrm{COI} \\
\text { or } \quad & \mathrm{M} 1=\mathrm{NFA}+\mathrm{NDA} 1 \\
\mathrm{M} 2 & =\mathrm{NFA}+\mathrm{DC}-\mathrm{COI}=\mathrm{M} 1+\mathrm{TD} \\
\text { or } \quad & \mathrm{M} 2=\mathrm{NFA}+\mathrm{NDA} 2
\end{array}
$$

M1 = Narrow money

M2 = Broad money

NFA $=$ net foreign assets from banking systems

DC = domestic creditfrom banking systems

$\mathrm{TD}=$ Timed Deposits in banks (deposit berjangka) 
$\mathrm{COI}=$ capital and other liabilities (net)

NDA1 $=$ net domestic assetsfrom banking systems

NDA2 = net domestic assetsfrom banking systems before calculating TD

\section{Research Methodology}

\subsection{Methods Used}

Analysis in this paper is descriptive to illustrate the facts and characteristics of the implication of BI's regulation to some variables systemically and accurately. By analysing quantitatively and qualitively using statistic procedure and simulation, we will be able to see the effect of a regulation to the financial condition in a period of time.

\subsection{Data Collection and Data Analysis Technique}

Data collected are qualitative and quantitative secondary data received from BI's published data and Indonesia's Statistic Institution Center. Then, we will use descriptive analysis by creating systematic, factual, and accurate illustration about facts, characteristics, relationship and correlation between the regulation to require the use of rupiah to the changes of the use of foreign currency in Indonesia.

The research model used in this paper is based on money quantity theory with regression described below.

\begin{tabular}{cc}
\hline Symbol & Explanation \\
\hline $\mathbf{U B}_{\mathbf{t}}$ & Amount of money circulated \\
$\mathbf{D V}$ & Foreign Currency Deposits \\
$\mathbf{D K P R}$ & Dummy Mandatory Use of Rupiah to differentiate before and after the regulation \\
$\mathbf{G V}$ & Demand Deposit in Foreign Currency \\
TV & Savings in foreign currency \\
GDP & Growth Domestic Product \\
CPI & Consumer Price Index \\
\hline
\end{tabular}

$$
\mathrm{UB}_{t}=\alpha_{0}+\beta_{1} \mathrm{DV}_{\mathrm{t}}+\beta_{2} \mathrm{DKPR}+\beta_{3} \mathrm{GV}_{\mathrm{t}}+\beta_{3} \mathrm{TV}_{\mathrm{t}}+\beta_{4} \mathrm{CPI}_{\mathrm{t}}+\beta_{4} \mathrm{GDP}_{\mathrm{t}}+\varepsilon_{\mathrm{it}}
$$

Using VAR, we will generate results showing how each variable responds to shocks caused by this regulation. The model is shown below.

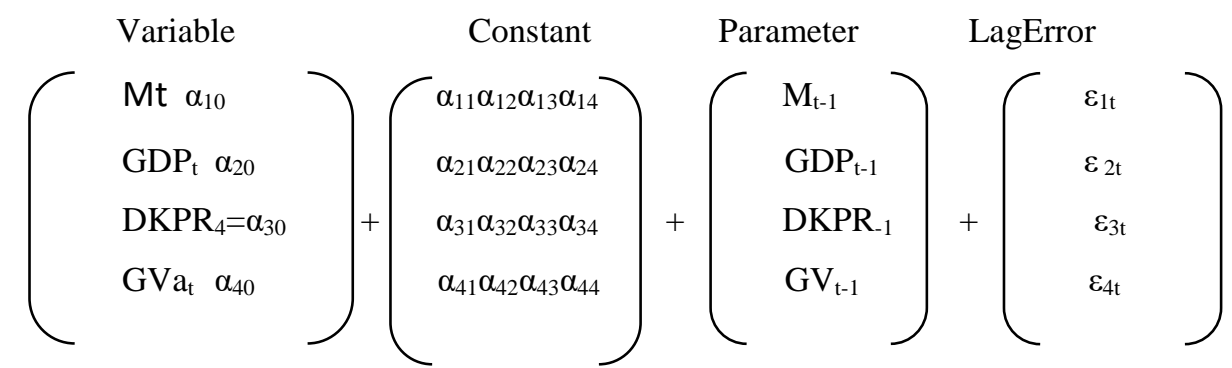

There are two approaches to see how this regulation affects the stability of rupiah using variables above. First, we should see the changes of the amount of foreign currency circulated and/or used in transaction in Indonesia. This can be seen from non-bank transaction in foreign currency, non-cash payment using foreign currency, demand deposit and savings in foreign currency. Second, we should look into the changes of the amount of rupiah used in Indonesia. This can be retrieved from the amount of checking and savings in rupiah. 


\section{Results}

\subsection{Non-Bank Transaction in Foreign Currency in Domestic Banks}

One of the ways in determing the effectiveness of BI's regulation is to see if there is any decrease in the usage of foreign currency in Indonesia. In September 2015, there is a decrease of foreign currency usage in terms of value compared to the monthly average from January - August 2015 from USD 5.19 million to USD 3.37 million. The frequency of transaction in foreign currency in September 2015 also decreased from 36,333 transactions on average in September 2014 - August 2015 to 18,000. It shows that the implementation of mandatory use of Rupiah decrease the use of USD in transaction between Indonesians.

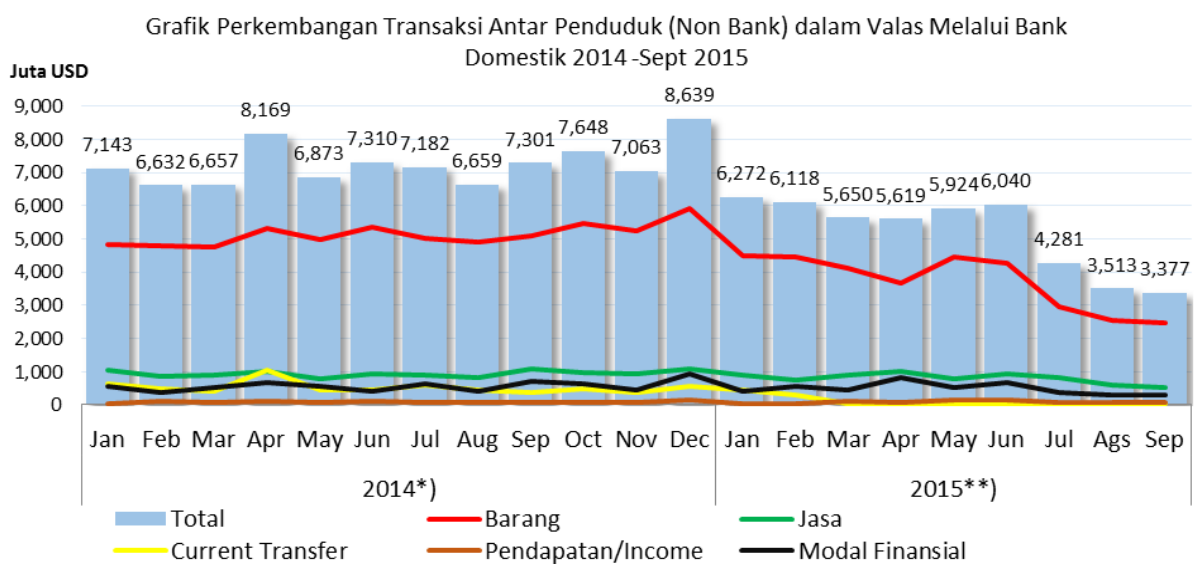

Figure. 3. Non-Bank Transactions in Foreign Currency in Domestic Banks in January 2014 - September 2015.

*) Temporary Number * **) Very Temporary Number Services Financial Capital Source: DSta and DPKL of Bank Indonesia

If we look into payments from Nostro to Nostro and Nostro to OCA since the implementation of BI regulation for non-cash transaction in June 2015 to three months after the implementation, we can see from graph below that noncash transactions in foreign currency decrease by $38 \%$.

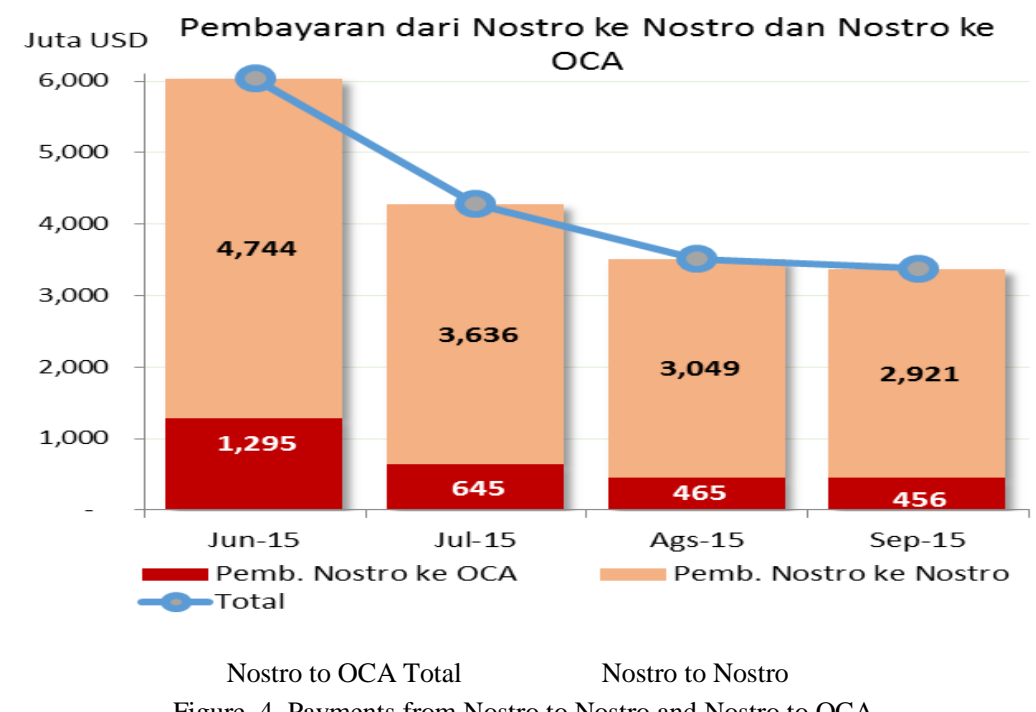

Figure. 4. Payments from Nostro to Nostro and Nostro to OCA. 


\subsection{Money in Circulation}

Below is a graph showing the amount of money in circulation for both M1 and M2 bi-monthly in January $2014-$ September 2015.

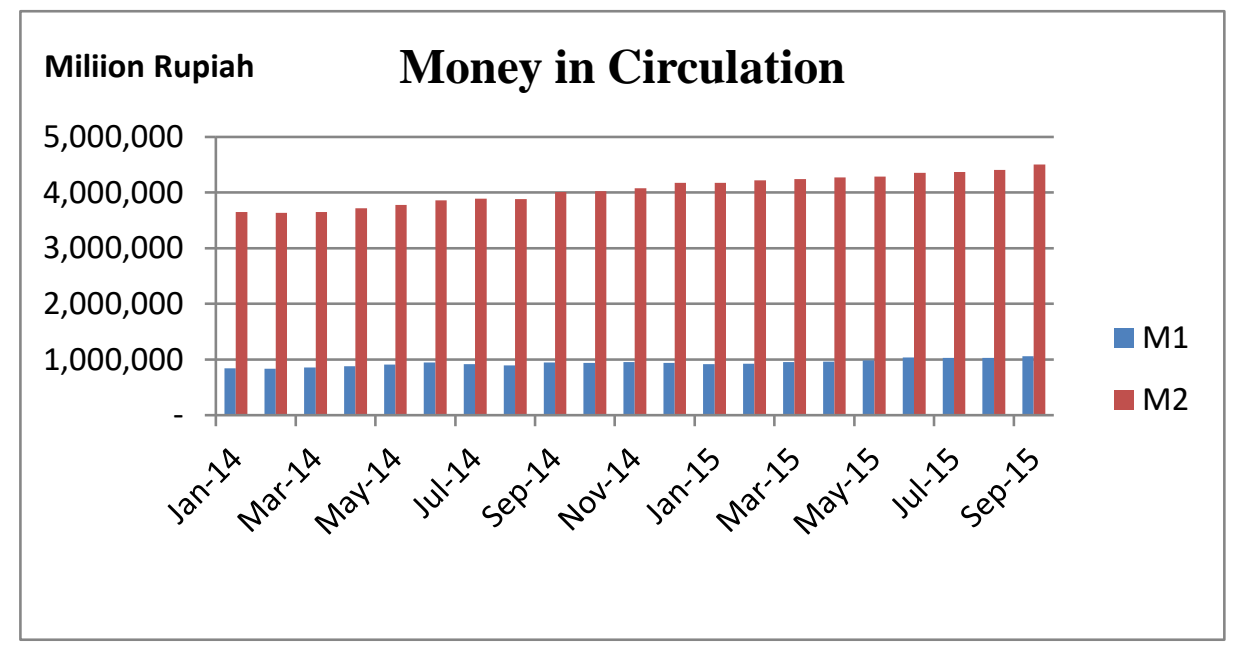

Figure. 5. Money in Circulation in January 2014 - September 2015.

Source: Bank Indonesia

There is an increase in the amount of money in circulation in 2015 compared to 2014 . We can see that the increasing trend had been happening before the regulation was implemented. Therefore, there are other factors that affect the amount of money in circulation, which are CPI and GDP.Detailed information about CPI and GDP can be found below.

\begin{tabular}{cccc}
\hline Variable & First Quarter 2015 & Second Quarter 2015 & Third Quarter 2015 \\
\hline CPI & 118.48 & 120.14 & 121.67 \\
DP (in trillion Rupiah) & $2,157.8$ & $2,239.3$ & $2,982.6$ \\
\hline
\end{tabular}

A more detailed analysis about each variable will be explained below.

\subsection{Currency outside bank, demand depositin rupiah andforeign currency, savings in rupiah and foreign currency, and $g d p$}

Using quarterly data from January 2013 - September 2015, we can see that savings in Rupiah (it includes savings account and deposits) increase from fourth quarter in 2013 to fourth quarter in 2014 and experience a higher increase since the second quarter of 2015 (after the implementation of the regulation). Similar trend has been happening to currency outside bank since second quarter of 2015. 


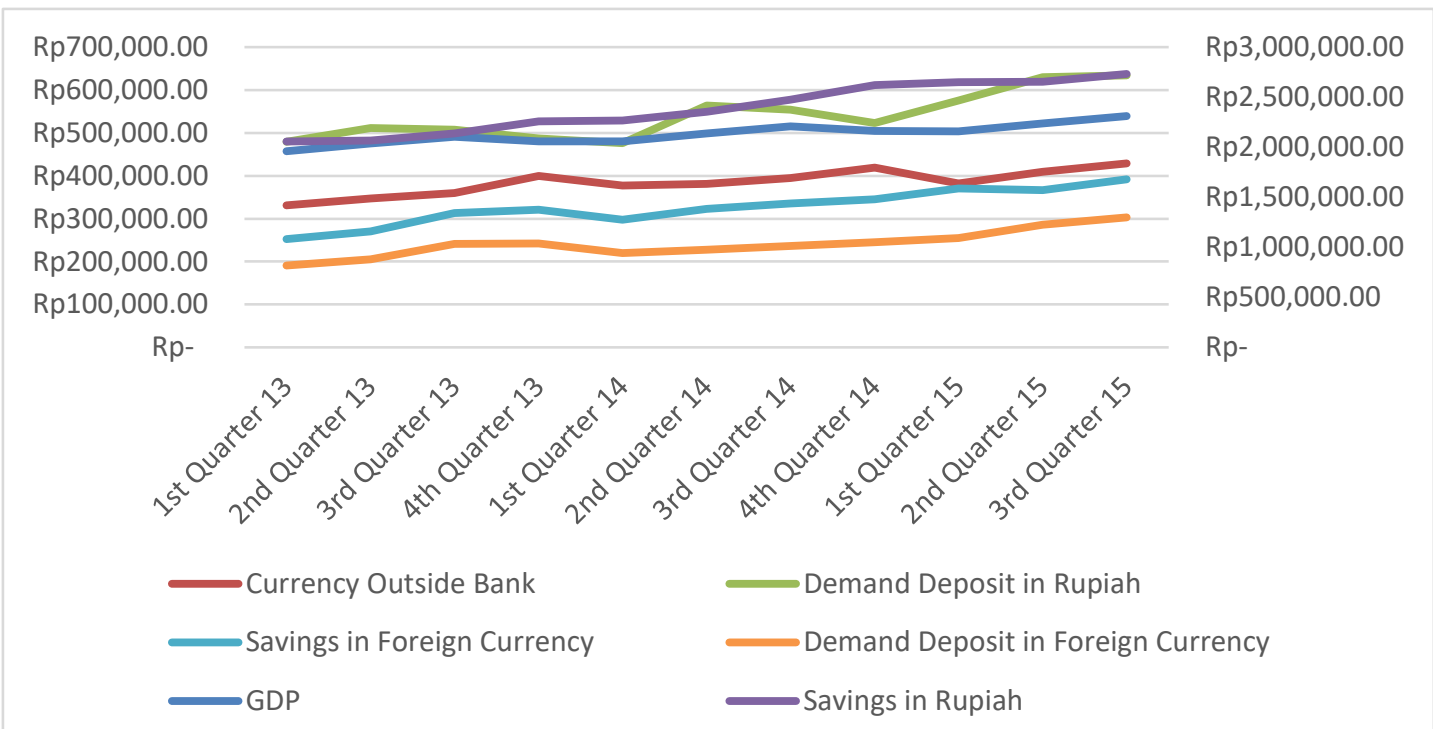

Figure. 6. GDP, Currency Outside Bank, Demand Deposit in Rupiahm Savings in Rupiah, Savings in Foreign Currency, Demand Deposit in Foreign Currency in January 2013 - September 2015 (in Million Rupiah)

GDP and Savings in Rupiah uses right-hand side axis

Source: www.bi.go.id

A more detailed data about GDP, currency outside bank, demand deposit in Rupiah and foreign currency, savings in Rupiah and foreign currency can be seen below.

Table. 2. GDP, Currency Outside Bank, Demand Deposit in Rupiahm Savings in Rupiah, Savings in Foreign Currency, Demand Deposit in Foreign Currency in January 2013 - September 2015 (in Million Rupiah).

\begin{tabular}{|c|c|c|c|c|c|c|}
\hline Period & $\begin{array}{l}\text { Constant } \\
\text { GDP }\end{array}$ & $\begin{array}{l}\text { Currency } \\
\text { Outside Bank }\end{array}$ & $\begin{array}{l}\text { Demand } \\
\text { Deposit in } \\
\text { Rupiah }\end{array}$ & $\begin{array}{l}\text { Savings in } \\
\text { Rupiah }\end{array}$ & $\begin{array}{l}\text { Savings in } \\
\text { Foreign } \\
\text { Currency }\end{array}$ & $\begin{array}{l}\text { Demand } \\
\text { Deposit in } \\
\text { Foreign } \\
\text { Currency }\end{array}$ \\
\hline $\begin{array}{l}1^{\text {st }} \text { quarter } \\
13\end{array}$ & $1,959,690$ & $331,168.76$ & $478,886.13$ & $2,057,109.45$ & $252,390.98$ & $190,841.39$ \\
\hline $\begin{array}{l}2^{\text {nd }} \text { quarter } \\
13\end{array}$ & $2,036,920$ & $347,146.05$ & $511,352.94$ & $2,067,209.57$ & $270,591.40$ & $205,484.35$ \\
\hline $\begin{array}{l}3^{\text {rd }} \text { quarter } \\
13\end{array}$ & $2,103,340$ & $360,078.55$ & $507,636.37$ & $2,137,916.64$ & $313,283.66$ & $240,771.78$ \\
\hline $\begin{array}{l}4^{\text {th }} \text { quarter } \\
13\end{array}$ & $2,058,250$ & $399,608.66$ & $487,474.84$ & $2,256,849.35$ & $321,255.14$ & $242,416.04$ \\
\hline $\begin{array}{l}1^{\text {st }} \text { quarter } \\
14\end{array}$ & $2,060,480$ & $377,437.65$ & $476,064.75$ & $2,267,532.41$ & $298,005.05$ & $219,638.62$ \\
\hline $\begin{array}{l}2^{\text {nd }} \text { quarter } \\
14\end{array}$ & $2,139,300$ & $381,637.54$ & $564,080.28$ & $2,352,854.50$ & $323,109.84$ & $227,450.90$ \\
\hline $\begin{array}{l}3^{\text {rd }} \text { quarter } \\
14\end{array}$ & $2,206,870$ & $395,229.50$ & $553,938.83$ & $2,473,531.40$ & $335,365.95$ & $235,944.54$ \\
\hline
\end{tabular}




\begin{tabular}{lllllll}
$4^{\text {th }}$ quarter & $2,161,460$ & $419,261.84$ & $522,959.50$ & $2,619,658.38$ & $344,811.93$ & $245,004.92$ \\
14 & & & & & \\
$1^{\text {st }}$ quarter & $2,157,760$ & $382,004.92$ & $575,575.54$ & $2,649,829.41$ & $370,448.51$ & $255,220.69$ \\
15 & & & & & \\
$2^{\text {nd }}$ quarter & $2,239,290$ & $409,713.13$ & $629,804.84$ & $2,653,103.79$ & $366,550.77$ & $285,986.22$ \\
15 & & & & & & $302,999.02$ \\
$3^{\text {rd }}$ quarter & $2,311,200$ & $428,860.24$ & $634,178.47$ & $2,731,587.05$ & $391,757.15$ & 302 \\
15 & & & & & & \\
\hline
\end{tabular}

In the second and third quarter in 2015, there is an increase in the amount of currency outside bank in circulation, demand depositin rupiah and foreign currency, and savings in rupiah. Savings in foreign currency experienced a decrease in second quarter in 2015 due to shock effect from the regulation that was implemented in March 2015.

Indonesians converted their savings in foreign currency to Rupiah to be saved again or used for transaction. However, savings in foreign currency increased in the third quarter because Indonesians are more aware of the importance of Rupiah in doing transactions. As a result, foreign currency that they have are saved in savings accounts or deposits (there is a $5.9 \%$ increase from second to third quarter). Percentage of increase and decrease of each variable can be seen below.

Table. 3. Increase/Decrease in Currency Outside Bank, Demand Deposit in Rupiah, Savings in Rupiah, Savings in Foreign Currency, Demand Deposit in Foreign Currency.

\begin{tabular}{lccccc}
\hline \multirow{2}{*}{ Period } & \multicolumn{3}{c}{ Increase/Decrease } \\
\cline { 2 - 6 } & $\begin{array}{c}\text { Currency } \\
\text { Outside } \\
\text { Bank }\end{array}$ & $\begin{array}{c}\text { Demand } \\
\text { Deposit in Rupiah }\end{array}$ & Savings in Rupiah & $\begin{array}{c}\text { Savings in Foreign } \\
\text { Currency }\end{array}$ & $\begin{array}{c}\text { Demand Deposit in } \\
\text { Foreign Currency }\end{array}$ \\
\hline Q1 toQ2 & $7.25 \%$ & $9.42 \%$ & $0.12 \%$ & $-1.05 \%$ & $12.05 \%$ \\
Q2 to Q3 & $4.67 \%$ & $0.69 \%$ & $2.96 \%$ & $6.88 \%$ & $5.95 \%$ \\
\hline
\end{tabular}

\subsection{Statistic Simulation}

Data used in statistic simulation for this paper are:

- GDPbased on price

- GDPbased on constant price

- Consumer Price Index (CPI)

- $\quad$ Narrow money(M1 = currency outside bank + demand depositin Rupiah)

- $\quad$ Broad money (M2 = M1 + Quasi Money(Deposits in Rupiah and foreign currency, Savings in Rupiah and foreign currency, and Demand Deposit in foreign currency) + marketable securitiesbesides stock)

- DummyMandatory Use of Rupiah, where period before its implementation is represented with " 0 " and "1" after the implementation

Simulation is done to know the correlation between the regulation and the changes of the use of foreign currency using indicators stated above. Data analysis is performed on EViews 7 by using Ordinary Least Square (OLS) method. The results are shown below: 
Table. 4. Explanatory Power "Effectiveness of Requiring the Use of Rupiah" Simulation.

\begin{tabular}{|c|c|c|c|c|}
\hline Fixed Variable $\rightarrow$ & $\begin{array}{l}\text { Money in } \\
\text { Circulation }\end{array}$ & $\begin{array}{l}\text { Money in } \\
\text { Circulation }\end{array}$ & $\begin{array}{l}\text { Money in } \\
\text { Circulation }\end{array}$ & Checkingin Rupiah \\
\hline \multicolumn{5}{|l|}{ Variable: } \\
\hline Dummy & $14144,87 * *$ & $26976,98 *$ & $18408,97 *$ & $84407,12 * * *$ \\
\hline \multicolumn{5}{|l|}{ Mandatory Use of } \\
\hline \multicolumn{5}{|l|}{ Rupiah } \\
\hline & 16958,83 & 15640,47 & 15644,78 & 18233,93 \\
\hline Deposits in & $0,327548^{*}$ & $0,618159 * *$ & & $7,40 \mathrm{E}-07 *$ \\
\hline \multicolumn{5}{|l|}{ Foreign Currency } \\
\hline & 0,294293 & 0,246108 & & $5,45 \mathrm{E}-06$ \\
\hline Checking in & $0,521317 *$ & & & $5,28 \mathrm{E}-06^{*}$ \\
\hline \multicolumn{5}{|l|}{ Foreign Currency } \\
\hline & 0,309503 & & & 18233,93 \\
\hline \multirow[t]{2}{*}{ CPI } & $50,29443^{*}$ & $134,2137 *$ & $618,1801^{*}$ & $-433,7709^{*}$ \\
\hline & 370,8522 & 379,3543 & 4115908 & 587,6299 \\
\hline GDP Constant & $448,81 * * *$ & $456,9067 * * *$ & $414,5634 * * *$ & \\
\hline \multicolumn{5}{|l|}{ Price } \\
\hline & 97,50324 & 100,5287 & 96,80492 & \\
\hline \multirow[t]{2}{*}{ Deposits in Rupiah } & & & $0,102292 *$ & \\
\hline & & & 0,063098 & \\
\hline \multirow[t]{2}{*}{ Savings in Rupiah } & & & $0,195775^{*}$ & \\
\hline & & & 0,154605 & \\
\hline Savings in Foreign & & & & $-1,76 \mathrm{E}-05^{*}$ \\
\hline \multicolumn{5}{|l|}{ Currency } \\
\hline & & & & $1,93 \mathrm{E}-05$ \\
\hline Observation & 33 & 33 & 33 & 33 \\
\hline Number of $\mathrm{N}$ & 33 & 33 & 33 & 33 \\
\hline R Squared & 92,01 & 91,17 & 92,19 & 72,15 \\
\hline D-W Statistic & 1,836365 & 1,724453 & 1,965334 & 1,913552 \\
\hline
\end{tabular}

We can see that current account and deposits in foreign currency give a positive contribution to the amount of money circulated even though its contribution is not significant. On the other hand, GDP based on constant price gives a significant contribution to the amount of money circulated.

\subsection{Autocorrelation Test}

To ensure that estimation and data used before are free from Autocorrelation and any classic assumption problem, we have done Autocorrelation test. Method used is Durbin-Watson (D-W). It assumes first order autoregressive AR (1). Hypothesis for this test are:

- H0: $\rho=0$ and H1: $\rho>0$, it means if $\mathrm{d}<\mathrm{du}$, H0is declined on level $\alpha$, so statistically there is a significant positive autocorrelation

- H0: $\rho=0$ and H1: $\rho<0$, it means if $(4-\mathrm{d})<\mathrm{du}$, H0is declined on level $\alpha$, so statistically there is a significant negative autocorrelation 
- H0: $\rho=0$ and H1: $\rho \neq 0$, it means if $d<\mathrm{du}$ or $(4-\mathrm{d})<\mathrm{du}$, H0is declined on level 2 a , so statistically there is a significant positive and negative correlation

Table. 5. Criteria Autocorrelation Test.

\begin{tabular}{ccc}
\hline Null Hipotesis & Estimation Result & Conclusion \\
\hline $\mathrm{H}_{0}$ & $0<\mathrm{dw}<\mathrm{dl}$ & Declined \\
$\mathrm{H}_{0}$ & $\mathrm{dl} \leq \mathrm{dw} \leq \mathrm{du}$ & No conclusion \\
$\mathrm{H}_{1}$ & $4-\mathrm{dl}<\mathrm{dw}<4$ & Declined \\
$\mathrm{H}_{1}$ & $4-\mathrm{du} \leq \mathrm{dw} \leq 4-\mathrm{dl}$ & No conclusion \\
No positive nor negative autocorrelation & $\mathrm{du}<\mathrm{dw}<4-\mathrm{du}$ & Accepted \\
\hline
\end{tabular}

Source: Basic Econometrics, DamodarN. Gujarati (2003)

Results from running Eviews are shown on Table 7.

Table. 6. Durbin-Watson Test for $\alpha=5 \%$.

\begin{tabular}{|c|c|c|c|c|c|c|c|}
\hline Simulation & D-W Stat & Observation (n) & $\begin{array}{l}\text { Independent } \\
\text { Variable (k) }\end{array}$ & $\mathrm{dl} *$ & $\mathrm{u}^{*}$ & $\mathrm{dl}$ & $\mathrm{du}$ \\
\hline & 1.883273 & & & 1.12698 & 81282 & 87302 & 18718 \\
\hline & 1.724453 & & & 1.25756 & 65110 & 74244 & 34890 \\
\hline & 1.965334 & & & 1.19272 & 72978 & 80728 & 27022 \\
\hline
\end{tabular}

Source: www.stanford.edu

Table.7. Conclusion from Durbin-Watson Autocorrelation Test.

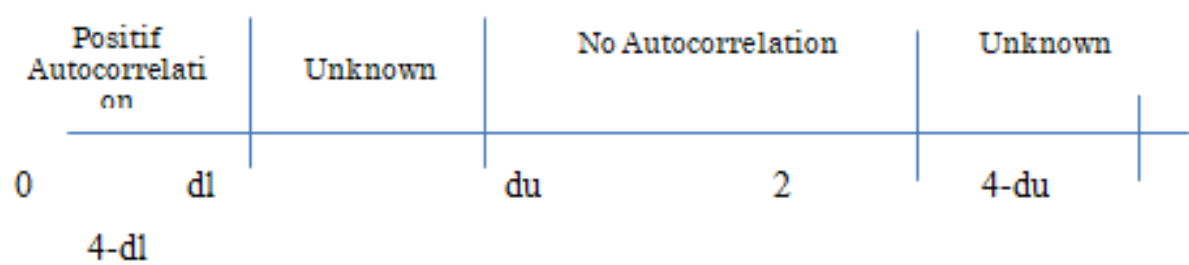

From Table 6 and 7, we can see that D-W statistics on all three simulations is within area $d u<d w<4-d u$, which means that there is no autocorrelation.

In addition, VAR test shows that impulse response from demand deposit in foreign currency to shocks of this regulation went through an increase from the first to third quarter since the policy implementation. However, moving forward, there is a new balance. 


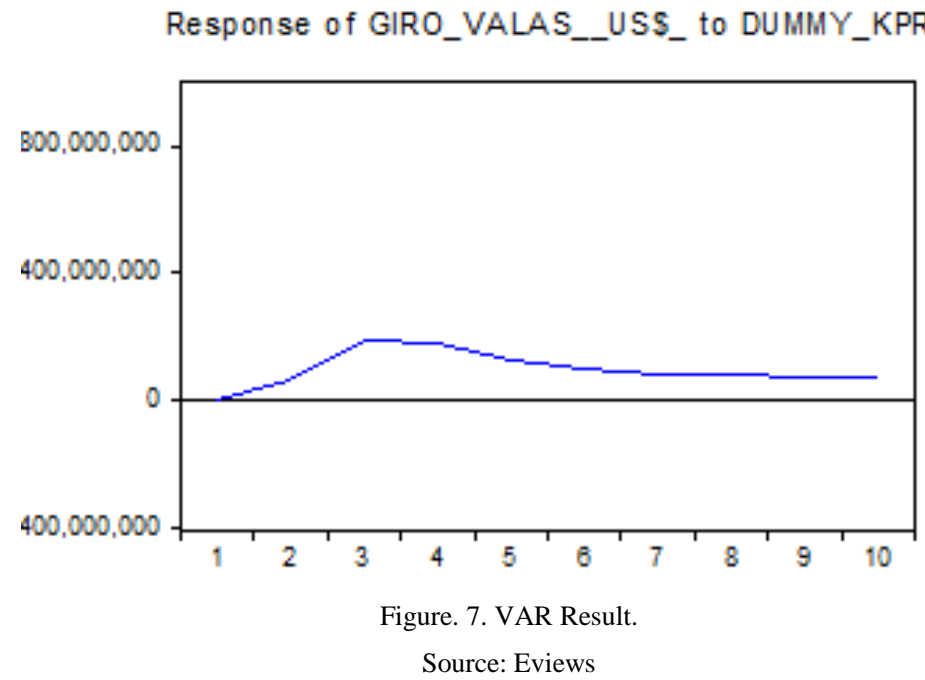

\section{Conclusion and recommendation}

\subsection{Conclusion}

Based on statistical simulation, we know that there is a positive contribution from requiring the use of Rupiah in Indonesia to Rupiah's stability, which is illustrated from:

- A decrease in the use of foreign currency in domestic transactions between residents

- An increase in the amount of rupiah in circulation. Even though, this increase is also caused by increase in CPI and GDP

- An increase in kartal money, demand deposit in rupiah and foreign currency, and savings in rupiah.

It decreases volatility of Rupiah which results in positive contribution to Rupiah's stability.

\subsection{Recommendation}

Further research has to be done to get a more in-depth analysis of the impact of mandatory use of Rupiah in Indonesia since data series used in this paper is limited, especially the period after the implementation (only 6 months). Using a wider range of data, for example one until two years after implementation will inform more significant data and information will be more beneficial, especially for testing second round effect financial instrument attached.

\section{References}

[1] Astria, R. (2015, May 10). Kewajiban Penggunaan Rupiah, Bank Sentral: BUMN Harus Berikan Contoh. Bisnis. Retrieved from http://finansial.bisnis.com/read/20150510/9/431779/kewajiban-penggunaan-rupiah-bank-sentral-bumn-harus-berikan-contoh

[2] Behera, H.K., Narasimhan, V., \& Murty, K.N. (2008). Relationship Between Exchange Rate Volatility and Central Bank Intervention: An Empirical Analysis for India. South Asia Economic Journal, 9 (1), 69 - 84.

[3] Boediono.(1985). Ekonomi Moneter (3rded.). Yogyakarta: BPFE.

[4] Business News Team. (2015, April 15). Menimbang Dampak Kewajiban Penggunaan Rupiah. Business News. Retrieved from http://www.businessnews.co.id/ekonomi-bisnis/menimbang-dampak-kewajiban-penggunaan-rupiah.php

[5] Carbaugh, R. J., \& Hedrick, D.W. (2009). Will the Dollar Be Dethroned as the Main Reserve Currency? Global Economy Journal, 9(3). Retrieved from http://www.cepal.org/noticias/paginas/3/35143/will-the-dollar-be-dethroned.pdf

[6] Chin, M. (2014). Central Banking: Perspectives from Emerging Economies. La Follette School Working Paper. Retrieved from http://www.lafollette.wisc.edu/images/publications/workingpapers/chinn2014-006.pdf

[7] Djiwandono, et al. (2006). Sejarah Bank Indonesia Periode III: 1966 - 1983 Bank Indonesia padaMasaStabilisasi, Rehabilitasi, dan Pembangunan Ekonomi. Jakarta: Bank Indonesia.

[8] Dominguez, K.M. (1998). Central Bank Intervention and Exchange Rate Volatility. Journal of International Money and Finance, 17(1),161190. 
[9] Elsherif, M.A. (2016). Exchange Rate Volatility and Central Bank Actions in Egypt: Generalized Autoregressive Conditional Heteroscedasticity Analysis. International Journal of Economics and Financial Issues, 6(3), 1209 - 1216.

[10] Festiani, S. (2015, July 7). Sentrabisnis di Jakarta Beralih Gunakan Rupiah. Republika. Retrieved from http://www.republika.co.id/berita/ekonomi/keuangan/15/07/07/nr481b-sentrabisnis-di-jakarta-beralih-gunakan-rupiah

[11] Garcia-Escribano, M.,\& Sosa, S. (2011). What is Driving Financial De-Dollarization in Latin America? IMFWorking Paper No. 11/10.

[12] Goodhart, C. (2010). The Changing Role of Central Banks. BIS Working Paper No. 326.

[13] Gujarati, D.N. (2003). Basic Econometrics (4th ed.). New York: Mc Graw Hill.

[14] Kasmir. (2011). Bank dan Lembaga Keuangan Lainnya. Jakarta: Raja Grafindo Persada.

[15] Koetter, M., Roszbach, K., \& Spagnolo, G. (2014). Financial Stability and Central Bank Governance. International Journal of Central Banking. Retrieved from https://www.ijcb.org/journal/ijcb14q4a2.pdf

[16] McKinze, M. (2004). An Empirical Examination of the Relation Between Central Bank Intervention and Exchange Rate Volatility: Some Australian Evidence. Australian Economic Papers, 43, 59 - 74.

[17] Mishkin, F.S. (2008). Ekonomi Uang, Perbankan, dan Pasar Keuangan (9thed.) (Lana Soelistianingsih \& Beta Yulianita Trans). Jakarta: Salemba Empat.

[18] Septiyaningsih, I. (2015, July 3). Gubernur BI Nyatakan Tak Semua Transaksi Gunakan Rupiah. Republika. Retrieved from http://www.republika.co.id/berita/ekonomi/keuangan/15/07/03/nqx765-gubernur-bi-nyatakan-tak-semua-transaksi-gunakanrupiahhttp://www.republika.co.id/berita/ekonomi/keuangan/15/07/03/nqx765-gubernur-bi-nyatakan-tak-semua-transaksi-gunakan-rupiah

[19] Septiyaningsih, I. (2015, July 6). Miris, 52 Persen Transaksi di Indonesia Masih Gunakan Valas. Republika. Retrieved from http://www.republika.co.id/berita/ekonomi/keuangan/15/07/06/nr2a9v-miris-52-persen-transaksi-di-indonesia-masih-gunakan-valas

[20] Singh, S.K. (2017). Currency Demand Stability in the Presence of Seasonality and Endogeneous Financial Innovation: Evidence from India. Journal of Financial Economic Policy, 9(2), 122 - 139.

[21] Sulaiman, S.R. (2015, April 9). JagaStabilitas Rupiah, BI Keluarkan Peraturan Baru. Kompas. Retrieved from http://bisniskeuangan.kompas.com/read/2015/04/09/154921326/Jaga.Stabilitas.Rupiah.BI.\%20Keluarkan.Peraturan.Baru 